\title{
Cultural Heritage to Build History for Life in Social Science Learning at Primary Schools
}

\author{
Arini Estiastuti \\ Department of Primary School Teacher Education \\ Universitas Negeri Semarang, Indonesia \\ ariniestipgsd@mail.unnes.ac.id
}

Kurniana Bektiningsih

Department of Primary School Teacher Education

Universitas Negeri Semarang, Indonesia

bektikurniana@yahoo.com

\author{
Atip Nurharini \\ Department of Primary School Teacher Education \\ Universitas Negeri Semarang, Indonesia \\ atip.nurharini@mail.unnes.ac.id \\ Munisah \\ Department of Primary School Teacher Education \\ Universitas Negeri Semarang, Indonesia \\ mountdbasyuni55@gmail.com
}

\begin{abstract}
Strengthening cultural heritage can be conducted by recognizing and empowering the heritage to keep implementing the values and philosophical meanings of culture in human life. To maintain, preserve, and develop cultural heritage, the solution can be done is by reviewing and analyzing cultural heritage by introducing, bringing up, and habituating local culture in students' life comprised in the social learning. The sampling technique employed random sampling, as many as 40 students. The research place was at a primary school in Semarang Barat. The techniques of data collection were observation, questionnaire, field notes, and documentation. The technique of data analysis was qualitative analysis using a descriptive method. The result of the study showed that teachers were able to explain, introduce, and get used to the cultural heritage well, for example: (a) ideas, (b) historical work including historical building, kingdom, folk art, museum, fairy tale, traditional dance, traditional music and instrument, traditional costume, traditional game, traditional food, traditional house, local language, customs, and (c) belief.
\end{abstract}

Keywords: cultural heritage, history for life, social learning

\section{INTRODUCTION}

Indonesian cultural wealth spreading out from Sabang to Merauke becomes a challenge and requires high dedication from Indonesian people to preserve, conserve, and develop culture. The nowadays culture is a heritage from ancestors, and the strong, creative, and innovative support builds up a strong cultural root of a nation. The strong cultural root does not cause a loss in cultural heritage. Strengthening cultural heritage can be done through recognition and empowerment in implementing values and philosophical meanings in human life.

The strengthening and empowerment are efforts to preserve the characteristics of cultural heritage and to manifest its existence through cultural history meaningfulness. As a man who respects nation, the man's identity should be strengthened and empowered. Not only distinguishing identity values, but also extending and preserving as well as positioning them to achieve existential construction. Existential construction is built up by understanding and transforming the identity symbols based on the cultural and historical domination behind the symbols. Cultural history of our nation is becoming a national identity which requires legal recognition and publication throughout the world. Culture is a way of living which is developed and owned together, and inheritable from one generation to another generation. Culture is created from a variety of complicated elements, including religious system, politics, values, rules, customs, languages, buildings, dress, and art work (Alwasilah, 2006). Culture cannot be separated from: (a) belief system, which is people's way in developing and building trust or belief in something will affect the evaluation system in the society; (b)aesthetic form, related to arts, music's, fairy tales, saga, drama, and dance developed in the society; and (c) language, which is communication meanings of the society (Hodder, 1999).

The result of the previous studies showed that Tabuik ceremony represents a reflection of the attitude and life pattern of Pariaman people. Moreover, Tabuik can be a social tradition which cannot be separated from Pariaman people"s life. Tabuik is followed by Anak Nagari in the form of Tabuik Culture. The meaning of Tabuik is created by each party. For people in general, Tabuik is an amusement. For government, Tabuik is a tourism agenda, while for Tabuik people, Tabuik is a cultural tradition which needs to be preserved. The desacralization process occurs because of challenges of the times, so Tabuik develops based on its ideology. Tabuk practice in the present is quite different from the past, however people still preserve it as a cultural tradition of Pariaman (Dalmenda \& Elia, 2017).

From the previous result, local tradition as a cultural heritage needs to be introduced in the education field. This attempt is to avoid culture elimination, human domination on the culture that has bound him, and slowly disappears. The loss of culture results in the disappearance of cultural symbols which once became the cultural strength. The reason behind this phenomenon is the development of contemporary culture, and it is trusted as an innovation which provides many positive impacts on human life. Furthermore, the effect of western culture without filtering process. This phenomena changes people's mindset to interpret modern changes and leave cultural heritage. The changes oddly happen simultaneously, not only in the youth but also in the 
elderly.

Similar phenomena occur at schools in this modernization era, indicated from a number of students who do not know their local culture as the cultural heritage of their ancestors. They do not understand history, origin, sacrifice of the ancestors, form, meaning, function, civilization, habits of their place. It is showed from the data in a primary school in Semarang Barat. Almost $90 \%$ of the fourth graders do not know identity values, identity characteristics, local arts, history, origin, meaning, habit, and custom of their city.

The interview result with the students when they were asked about the history of Semarang, they answered "no idea", when asked about the typical characteristics of Semarang, they answered "no idea", when asked how to make lumpia, kue mouci, bandeng presto, wingko babat, they answered "no idea", when asked about the local heroes, historical buildings, the year of establishment, and who built the buildings, they answered "no idea". The ignorance of students is not only about their city, but also about other cities. This phenomenon requires us as researchers, educators, humanists, and historians to give our attention to the next generation.

To preserve, conserve, and develop cultural heritage, a solution that can be done is reviewing and analyzing cultural heritage by introducing, bringing up, and habituating local culture in the students' life comprised in the social learning. Social learning at the primary school is an integration of various social science branches for example: sociology, history, geography, economy, politics, legal study, and cultural study. Social learning actualizes an interdisciplinary approach from several aspects and branches (Triatno, 2007). Social science plays a role in creating good citizens, including educating students to be good citizens, teaching them to solve social problems and to inherit national culture (Sutrisna, 2012). Therefore, design and strategy are needed so that students can know, get used to, love, preserve, conserve, and develop cultural heritage as the history for life. Introducing museums and art galleries to the students which involves public and researchers is a useful interaction process (Wilson, Fisher, Crossen, \& Hemingway, 2018).

\section{METHODS}

The location of this research was two primary schools in Semarang Barat, in particular, SDN Karangayu 02 and SDN Tambakaji 02 Semarang. The data needed in this study was obtained through several techniques as follows:

1. Observation Technique. Observation is an activity of observing something without affecting and simultaneously recording to be analyzed. In the above definition, there are two points to notice: observation of all things and making notes of the data and the phenomena.

2. Documentation Technique. Documentation is a note or record of the important past events. Documentation can be one's texts, pictures, or monumental work.

3. Field Notes Technique. Field notes technique includes notes of the researcher's activities during learning. The notes comprise important events during learning activities.
The sampling technique was random sampling with 40 students. The framework of the study and the research design can be seen as follows (Figure 1). The technique of data analysis employed in this study was qualitative analysis using descriptive method. In line with Bogdan and Tylor (in Moleong, 2005), qualitative data is a data presented in words, sentences, and pictures. A qualitative study produces qualitative technique through reducing data and presenting research procedure which generates descriptive data in the form of written or spoken words from people and the behavior observed. In the reduction data, the researcher analyzed the data comprehensively, then the data were selected in details for each part. Qualitative studies have five characteristics: (1) natural setting as the direct data source and researcher as the key instrument, (2) descriptive, (3) emphasizing the process instead of the result, (4) inductive data analysis, and (5) meaning as the main concern. In this qualitative study, the research procedure produced descriptive data in the form of written or spoken words from people and their behavior which can be observed.

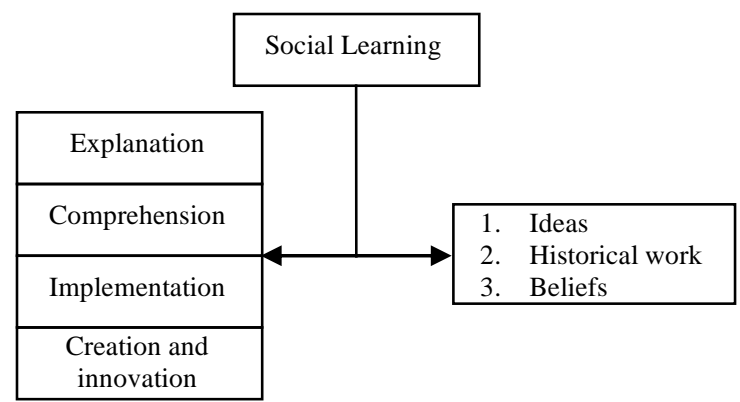

Figure 1

The Framework of the Study and the Research Design

\section{RESULTS}

\section{A. Cultural Heritage in Social Science Learning}

In social science learning activities, teachers explain, introduce, and engage students to share opinions about cultural heritage in Indonesia. The teaching process involves the use of information and technology. Preserving cultural heritage by implementing ICT aims to conserve the existence and development of cultural heritage (Machidon \& Octavian, 2018). Based on the data analysis, the result showed that cultural heritage such as historical buildings, traditional arts, traditional music's, traditional dance, and customs are the creators' ideas as the result of social behavior and environment. For example, Dugderan tradition in Semarang is a reflection of activities done by Semarang people (Figure 2). Dugderan is a ceremony which indicates the fasting month (Ramadhan) is coming. In the past, Dugderan was used as a media of Semarang Government to inform people about the coming Ramadhan. Dugderan is held one day before the fasting month. The word Dugder, is taken from the sound of dugdug and the sound of cannon assumed as "derr". Dugderan culture cannot be separated from the ideas of Semarang cultural actors, by presenting a typical and unique culture, considering it is generally defined as a human process or result of creation, invention, feeling, and intention in facing the life challenges from the surrounding nature. 
The typical characteristic of Dugderan is public market staring from a month from dugderan, carnival by a group of "red and white", drum band, a group of traditional dances "Bhinneka Tunggal Ika", cannon, warak ngendhog, and various arts potentials of Semarang. The uniqueness of this event is warak ngendhog, which is a fictional animal in the form of goat with a dragon head and golden scale skin, and the visualization is from colorful paper. This event is started from 8 am to maghrib time, and on the same day there is warak festival and Jipin Blantenan. The activities, action, and interaction of Semarang people in welcoming Ramadhan are realized by participating in the Dugderan ceremony (Figure 3; Figure 4). Dugderan is becoming more attractive for Semarang people, which is indicated by the enthusiasm of people in doing various activities such as selling, even there are sellers from other cities who sell food, drinks, and children toys made of clay (celengan, gerabah), bamboo (flute, gangsingan), paper (warakngendhog).

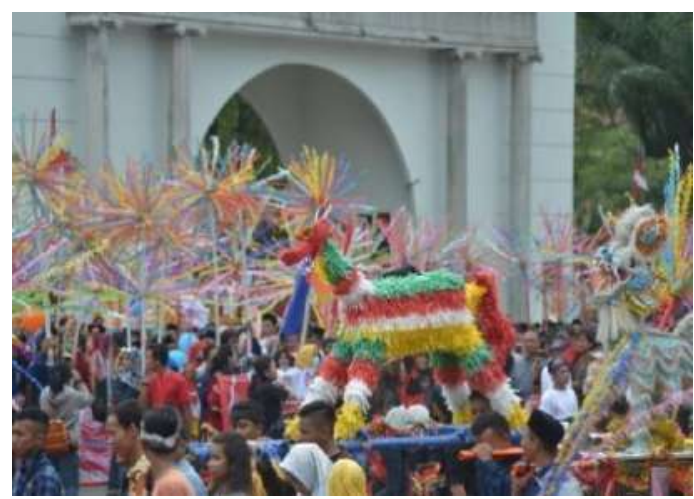

Figure 2

Dugderan Ceremony

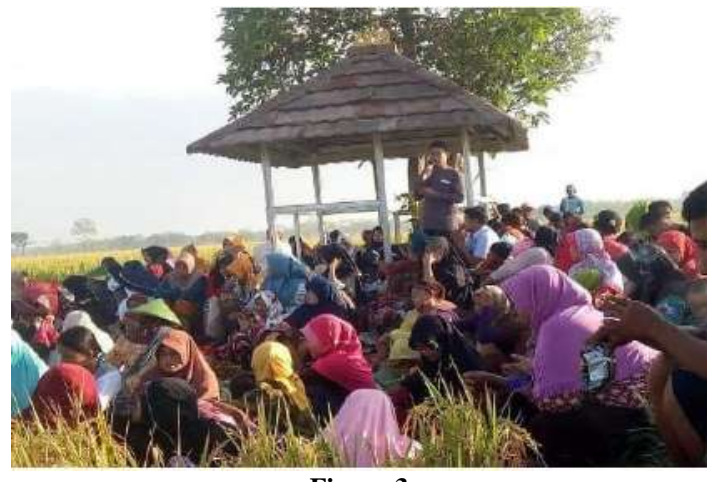

Figure 3

Social Interaction of Religious

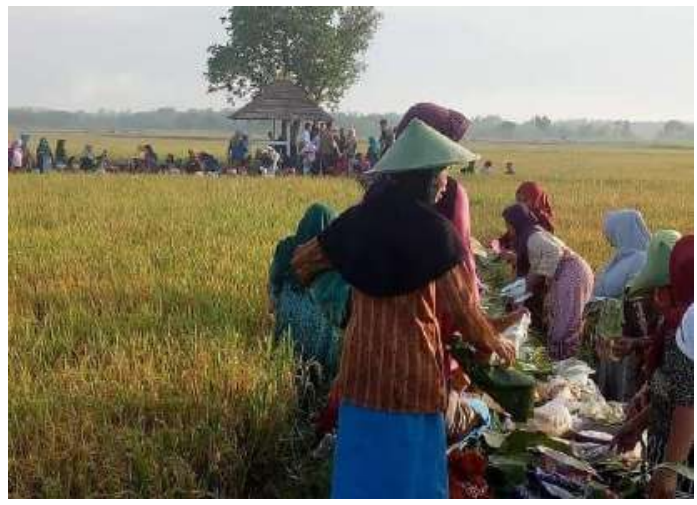

Figure 4

Sedekah Bumi

\section{B. Historical Work}

1. Historical buildings

The teachers explain and introduce historical buildings in Indonesia including those in Semarang, for example Sam Poo Kong (Figure 5) and Lawang Sewu (Figure 6).

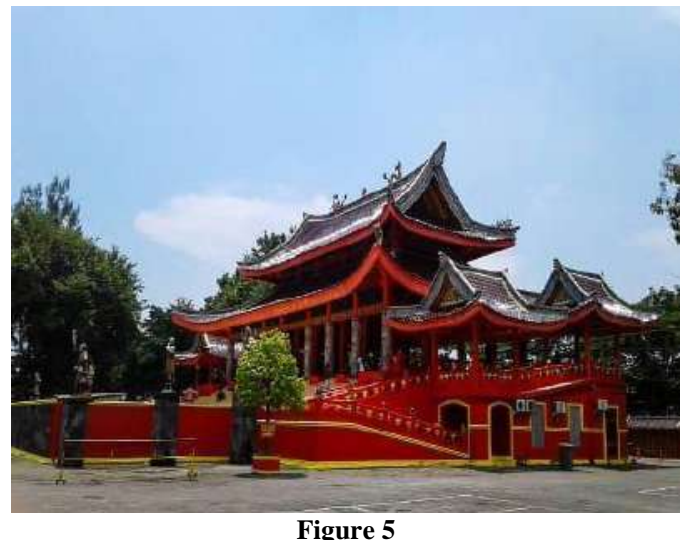

Sam Poo Kong

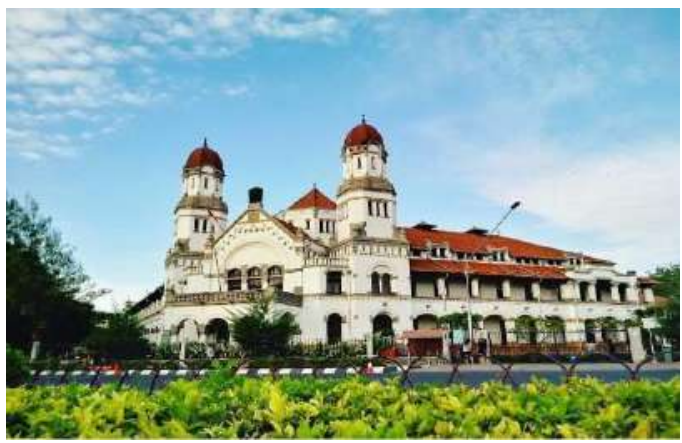

Figure 6

Lawang Sewu

2. Kingdom

The teachers explain and introduce several kingdoms in Indonesia. For example, in Central Java, there is a heritage of Mataram Hindu kingdom, which is Gedong Songo Temple (Figure 7), and Islamic kingdom heritage in Java which is Kudus Tower (Figure 8).

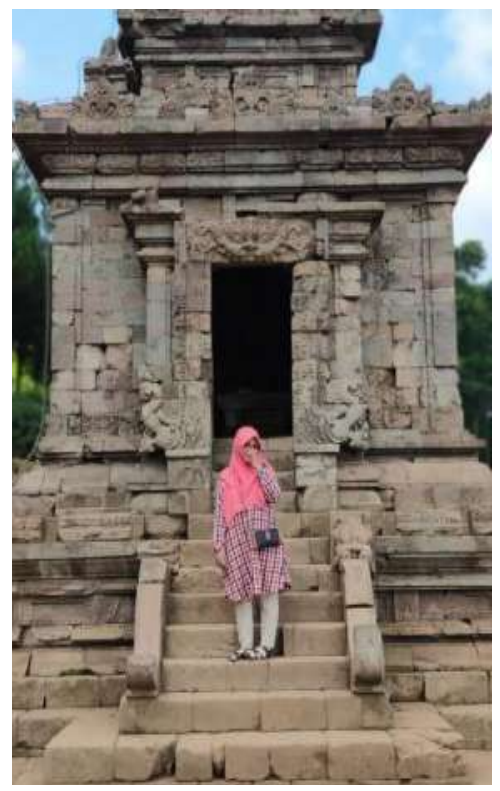

Figure 7

Gedung Songo Temple 


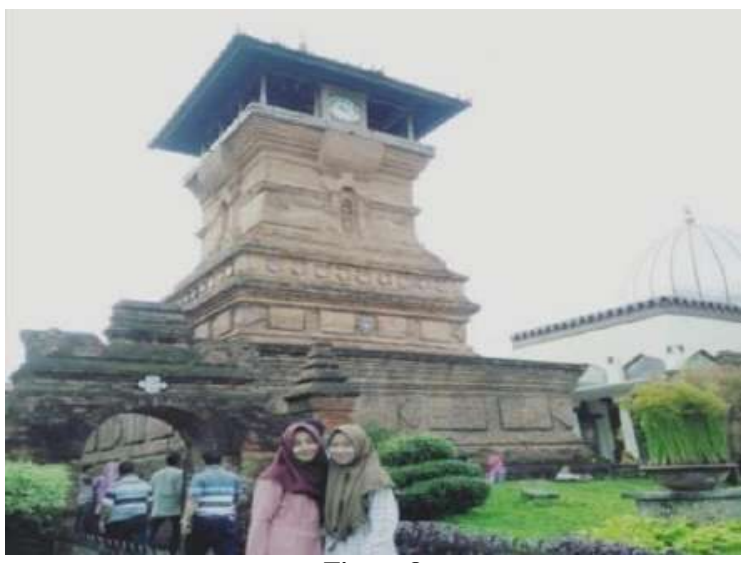

Figure 8

Kudus Tower

\section{Folk Arts}

The teachers explain and introduce that Indonesia has a variety of folk arts, for example, in East Java particularly Ponorogo there is Reog Ponorogo (Figure 9) and Warok (Figure 10).

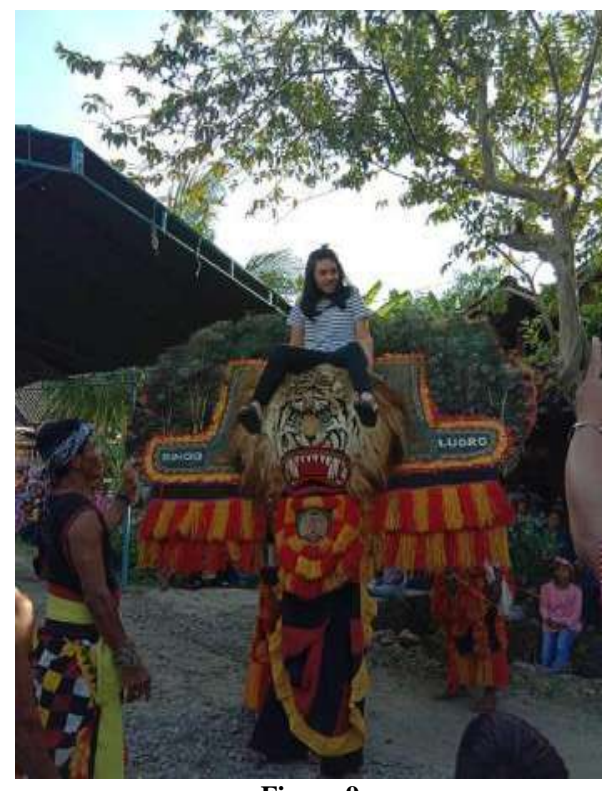

Figure 9

Reog Ponorogo from East Java

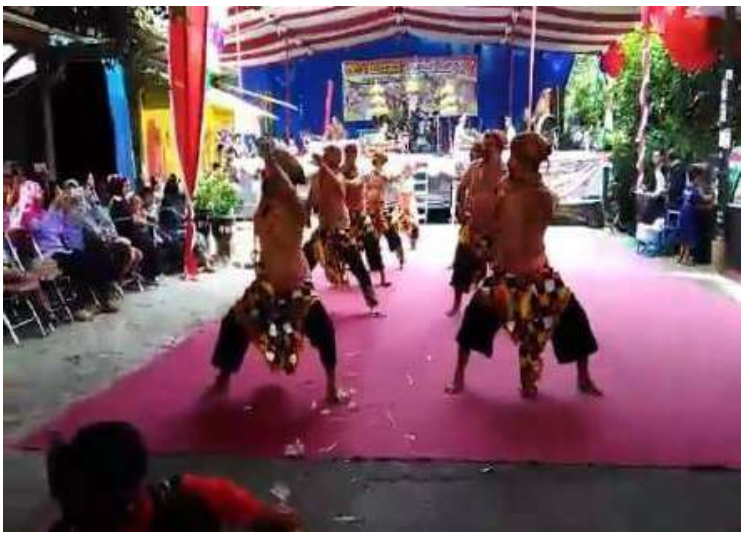

Figure 10

Warok Dance

\section{Museum}

The teachers explain and introduce museums in Indonesia, for example, there is Ronggowarsito museum in Central Java (Figure 11).

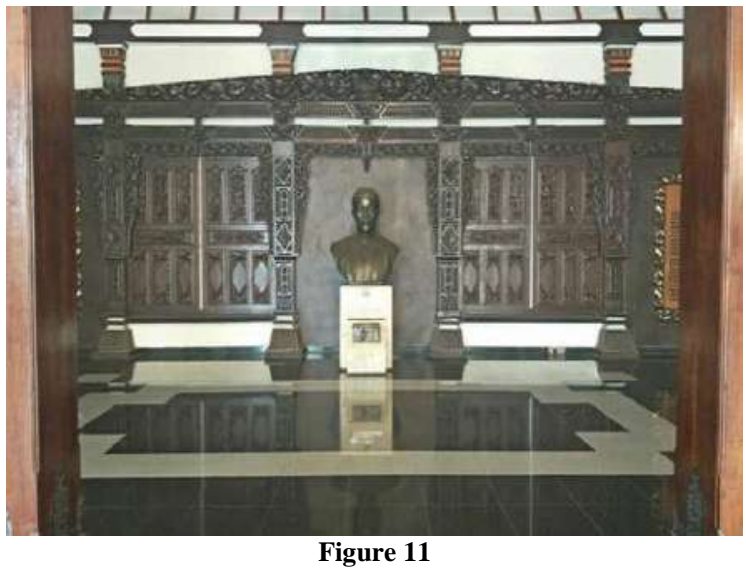

Ronggowarsito Museum

5. Legends

The teachers explain and introduce legends from: (1) West Java including Lutung Kasarung, Sangkuriang, and Mundinglaya Dikusumah, Leungli; (2) Central Java such as Aji Saka, Jaka Linglung, Legenda Jaka Tarub, Rara Jonggrang, Rara Mendut, and Suringgotho; (3) East Java such as Ande-ande Lumut, Aryo Menak, Damar Wulan, Kek Lesap, Keong Mas, Legenda Sri Tanjung, and Sarip Tambak Oso; (4) Central Kalimantan including Sampuraga; (4) Riau such as Kisah Pulau Senua, Putri Pandan Berduri, Batang Tuaka, Bawang Merah Bawang Putih, Legenda Batu Rantai, Putri Kaca Mayang, Putri Tujuh; (5) North Sumatra such as Mandailing Natal; (6) West Sumatra such as Danau Maninjau Legend, Lebai Malang, Maling Kundang, and Siamang Putih; and (7) Bali such as Pan Balang Tamak and I Gusti Gede Pasekan.

\section{Traditional Dance}

The teachers explain and introduce traditional dances of Indonesia, including in Central Java, East Java, West Java, Kalimantan, Sulawesi, Sumatera, and Bali. During learning process, the teachers present traditional dances, for example from Central Java there are Banyu Traditional Dance (Figure 12), Gambyong dance (Figure 13), Bondhan dance, Merak dance, and Kuda Lumping dance.

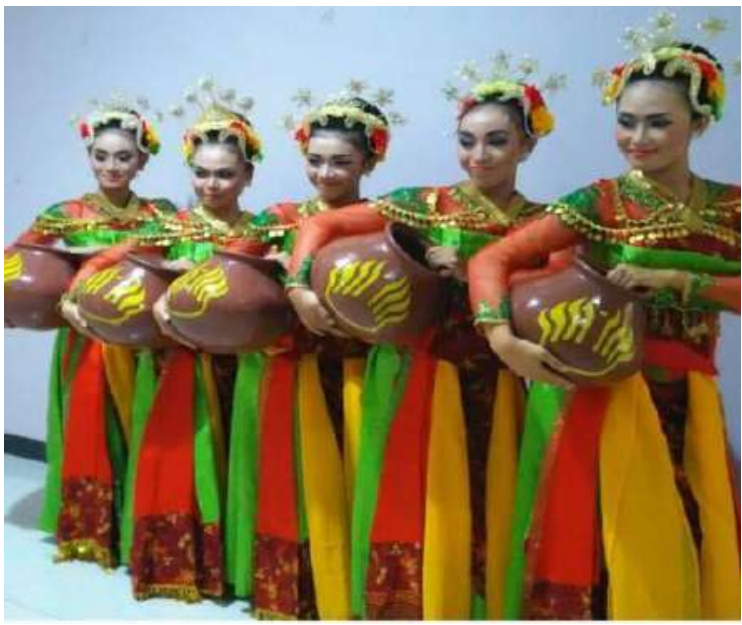

Figure 12

Banyu Traditional Dance 


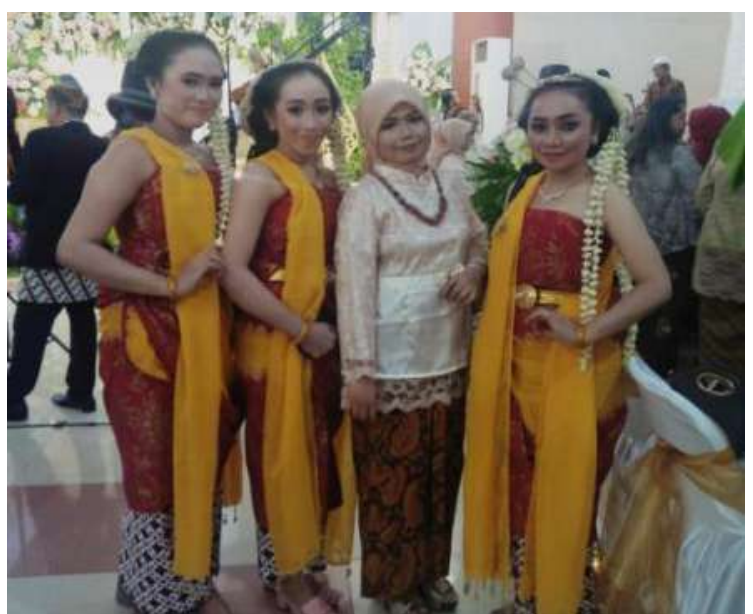

Figure 13

Gambyong Dance from Central Java

7. Traditional Music and Instrument

The teachers explain and introduce traditional music of Indonesia such as from Central Java and West Java. During learning process, the teachers ask the students to observe and practice traditional music of Central Java such as gamelan (Figure 15), as well as kolintang and angklung from West Java (Figure 14).

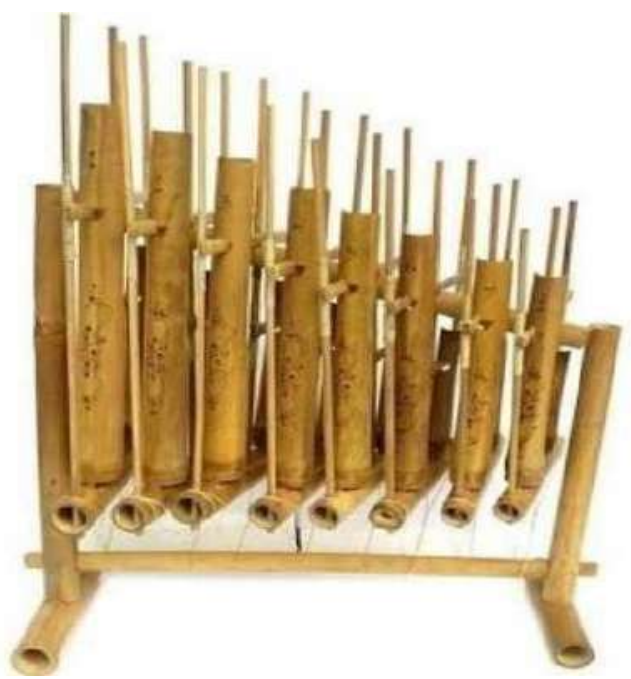

Figure 14

Angklung Music Instrument

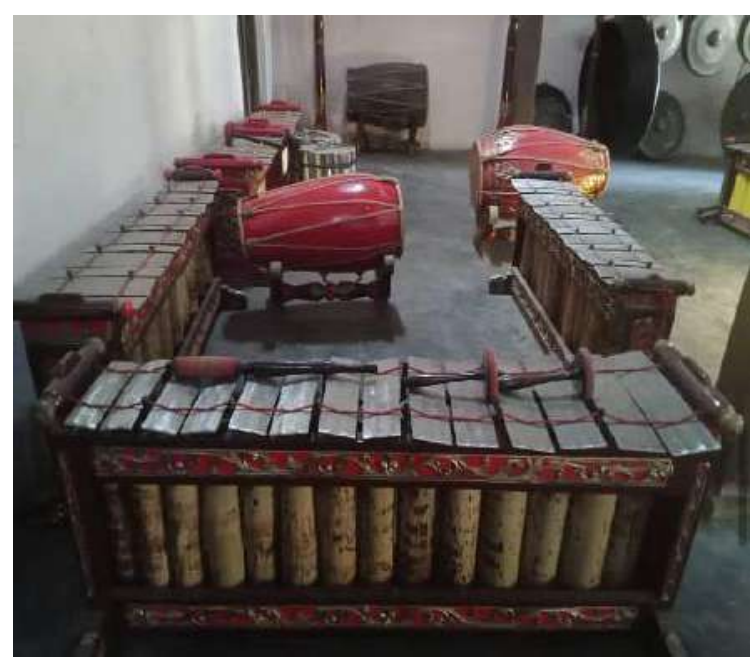

Figure 15

Traditional Music Instruments

\section{Traditional Dress}

The teachers explain and introduce traditional dress of Indonesia such as from Central Java. After introducing the traditional dress (Figure 16), the teachers ask the students to observe traditional dress including the color, model, accessories, properties, costumes, and dressing technique.

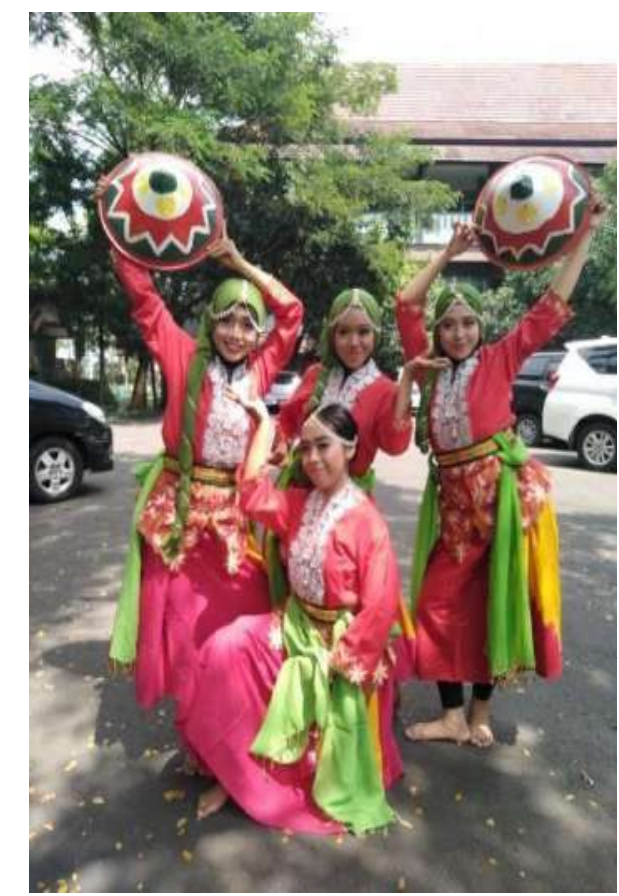

Figure 16

Traditional Dance

\section{Traditional Games}

The teachers make a plan and conduct traditional games in social science learning. Students are introduced and practice various traditional games such as: jamuran (Figure 17), betengan, bentik, egrang, lompat tali, cublakcublak suweng, bak sodor, and ular naga (Figure 18). In the traditional games, the teachers make students work together, respect, help, tolerate, fond of each other, and be responsible. After practicing traditional games, students are asked to write the game technique, the game origin, game pattern, and game characteristics. The result of the games is discussed in group and presented in front of other groups. After that, other groups pose questions and answers.

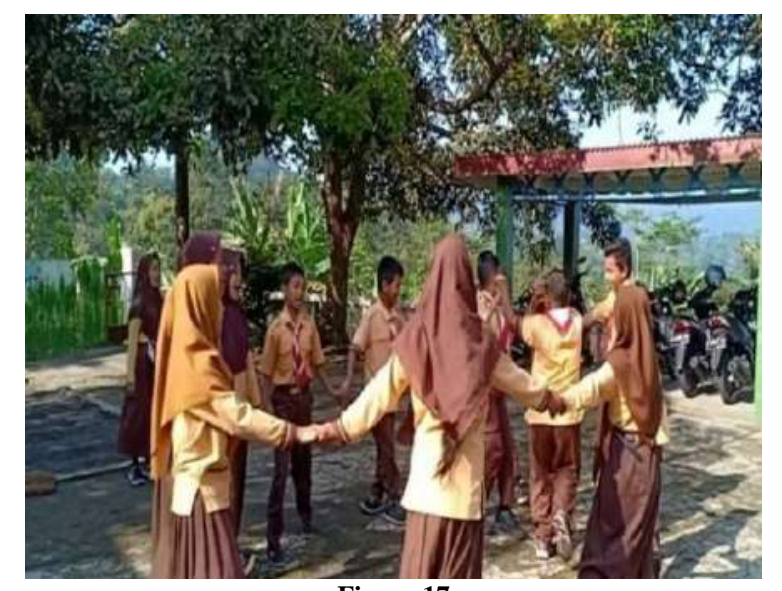

Figure 17

Jamuran Game 


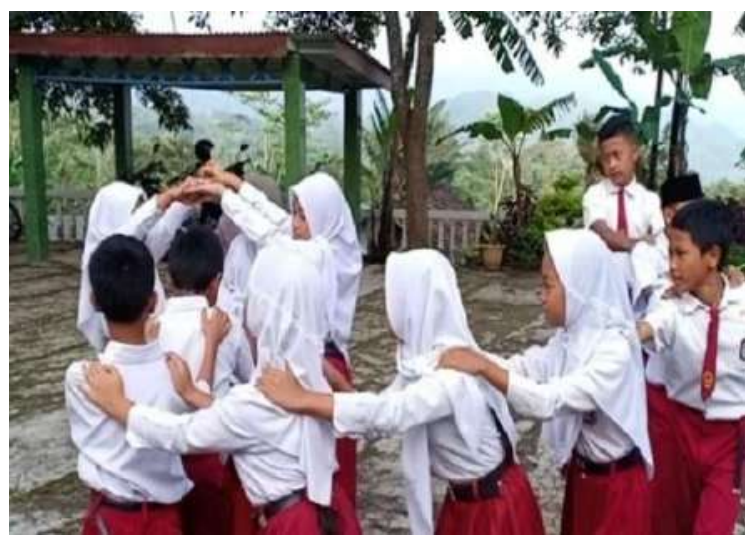

Figure 18

Ular Naga Game

10. Traditional Food

During learning process, the teachers introduce and ask students to taste the traditional food (Figure 19) and describe the ingredients and how to make the food. Students have a chance to present the description, and eat together with their friends (Figure 20). After the presentation, students share food they bring with each other.
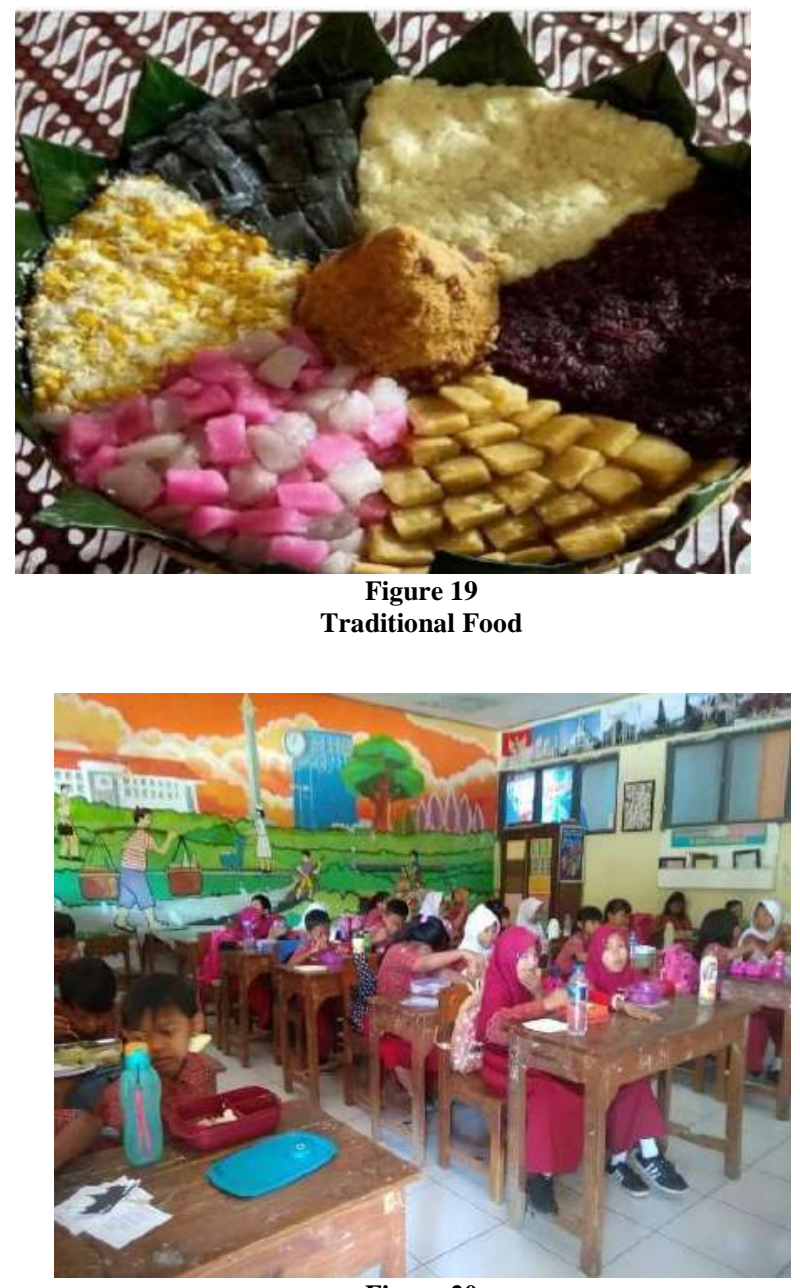

Figure 20

Eating Traditional Food Together

\section{Traditional House}

In the learning process, the teachers explain and introduce traditional house as cultural heritage of the ancestors. The traditional house introduced to the students is traditional house of Central Java named Joglo (Figure 23), traditional house of North Sumatera named Bolon (Figure 21), traditional house of West Sumatera named Gadang (Figure 22), traditional house of Nangroe Aceh Darusalam named Krong Bade, traditional house of Bangka Belitung named Limas, traditional house of West Java named Sunda, traditional house of DKI Jakarta named Kebaya, traditional house of DI Jogyakarta named Bangsal Kencono, traditional house of Bali named Gampura Candi Bentar, traditional house of Central Kalimantan named Betang, traditional house of North Sulawesi named Pewaris.

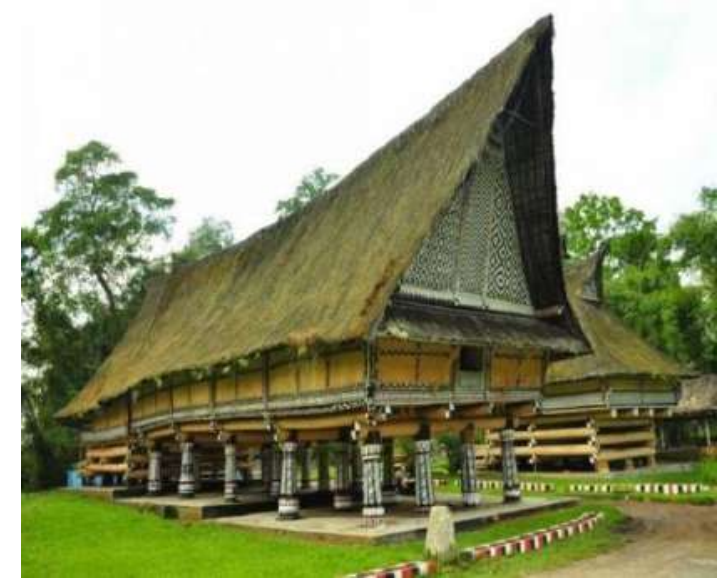

Figure 21

Traditional House of North Sumatera

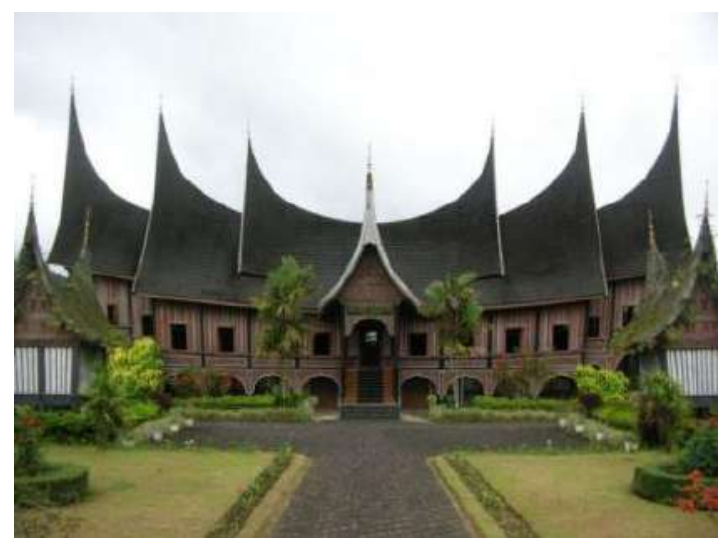

Figure 22

Traditional House of West Sumatera

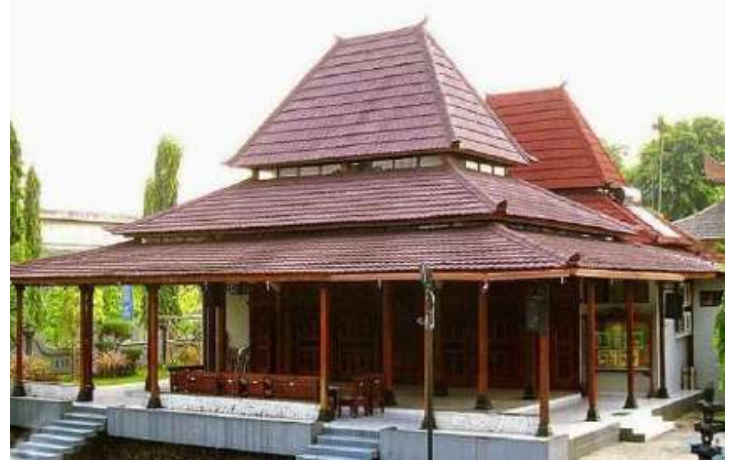

Figure 23

Traditional House of Central Java 


\section{Traditional Language}

The teachers explain and practice traditional languages in Indonesia such as Javanese, Sundanese, East Java, Madura, Batak, Minangkabau, Bugis, Aceh, Bali, and Melayu languages.

\section{Customs}

The teachers explain and introduce customs of each region. The customs include siraman ceremony (Figure 24) and sungkeman (Figure 25) in the wedding ceremony of Central Java.

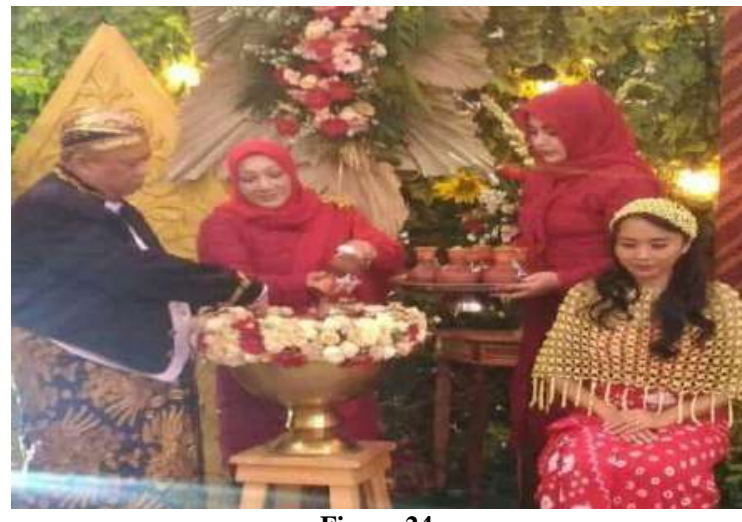

Figure 24

Siraman of Central Java

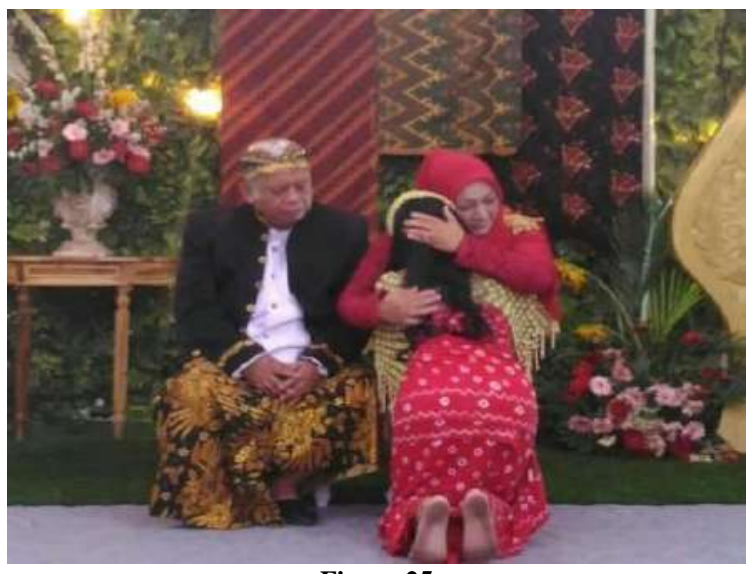

Figure 25

Sungkeman Tradition

\section{Beliefs}

The teachers explain some beliefs/religions in Indonesia, such as Islam (Figure 27), Christian/Protestant (Figure 26), Hindu, Buddhist, Kong Hu Chu.

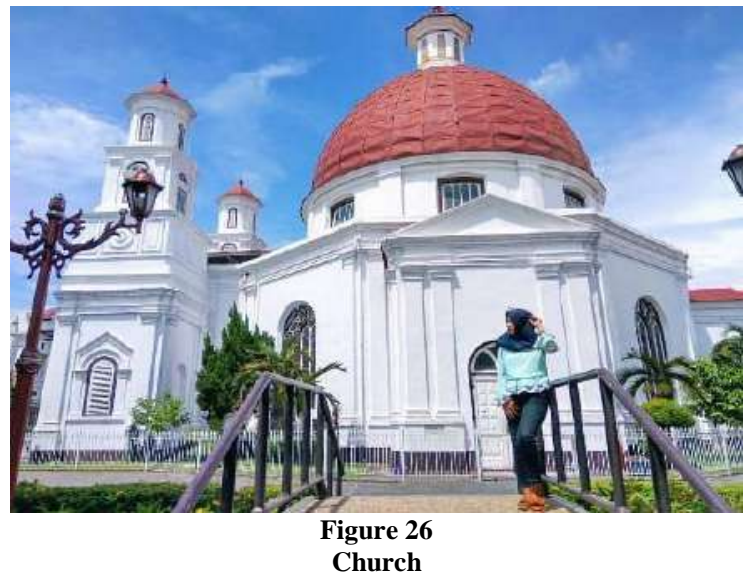

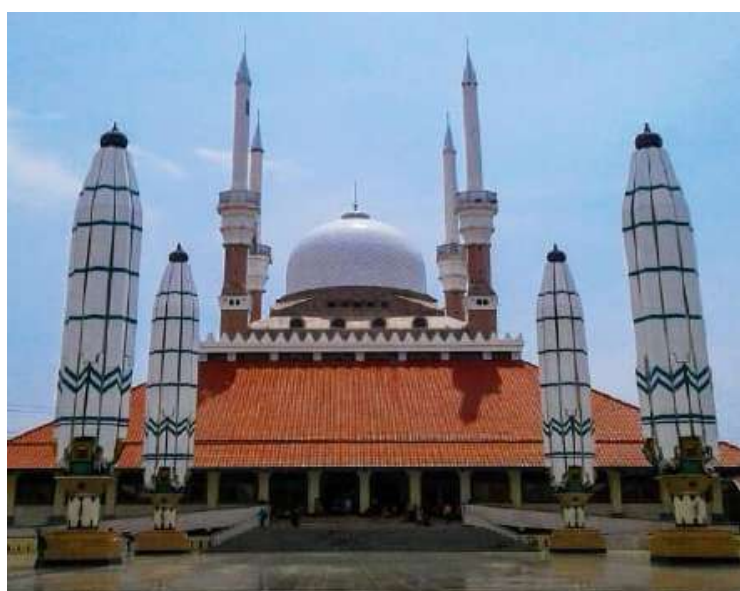

Figure 27

Masjid Agung

\section{DISCUSSION}

Culture is a complex issue which involves knowledge, beliefs, arts, laws, morality, customs as well as other culture which an individual obtains as a part of society (Majie, 2002). Ideas, objects and idealism behind cultural heritage need to be preserved, introduced and conserved by students. The success of preserving cultural heritage depends on the school curriculum that includes cultural heritage such as introducing motifs, pattern, and tradition to students in the learning activities. In line with the result of a study by Hendrawati and Ermayanti (2016) about motifs and patterns of weaving in Halaban village which is found to be the same with the weaving in Pandaisikek, and until now, Halaban villagers still preserve the original motifs. Activity, action, interaction and social system which become cultural heritage can be introduced to students in the social learning process. However, there are several obstacles in delivering the materials because of the abundant cultural heritage in Indonesia.

The teachers explain and introduce cultural heritage to students, for example: (a) ideas, (b) historical work including historical buildings, kingdom, folk arts, museums, legends, traditional dance, traditional music ad instrument, traditional dress, traditional house, local languages, and customs, and (c) beliefs. Students are able to know, respect, preserve, and develop local creation as cultural heritage if the teachers can explain and familiarize students with cultural heritage as the history of life, hence, it turns into students ${ }^{\text {ee }}$ habit. Introducing cultural heritage to students is a form of environmental awareness in respecting local culture.

Environmental and cultural awareness, in fact, are two inseparable things. It is because culture grows and lives in the existence of an environment. Culture cannot be separated from adaptation process with the environment. Therefore, it is not surprising if there is an assessment of environmental damage later because of nature exploitation which in turn causes cultural degradation or "cultural amnesia" within society (Geria, 2005). Cultural degradation of the students can be solved through the habituation of local cultural heritage so tradition can always be preserved as national identity.

Similar to the result of study about horse tradition in the wedding of Alas Tribe, the tradition has important 
meaning for people in South East Aceh, particularly in Alas Tribe, so they always use horse in their tradition. The result of the study showed that horse in the wedding ceremony tradition of Alas tribe in South East Aceh. Horse was firstly used as a riding animal by people in Alas tribe. The people use horses in the wedding as a symbol of freedom, intelligence, and strength. Therefore, all people still preserve the tradition of using horses in the wedding ceremony (Dermawan, Wawan, Puspitawati, 2019). Preserving traditions and cultural heritage can be history life for students, as students are familiar with cultural heritage of Indonesia.

\section{CONCLUSION}

Students in the fourth grade are able to know, understand, and recognize cultural heritage implemented in daily life. It is due to the teachers able to elaborate, introduce, and habituating students with cultural heritage during social science learning well. The introduction and heritagization of cultural heritage including: (a) ideas, (b) historical work such as historical building, kingdom, folk arts, museums, legends, traditional dance, traditional music and instrument, traditional dress, traditional games, traditional food, traditional dance, local languages, customs, and (c) beliefs.

\section{REFERENCES}

[1] Alwasilah. 2006. Ilmu Pelestarian Budaya. Bandung:
Rineka Cipta.

[2] Dalmenda, M. A., \& Novi Elia. 2017. Makna Tradisi Tabuik Oleh Masyarakat Kota Pariaman (Studi Deskriptif Interaksionisme Simbolik. Jurnal Antropologi: Isu-isu Sosial Budaya, 18(2), 135-151.

[3] Dermawan, Wawan, Puspitawati. 2019. The Meaning of Horses in the Tradition of the Marriage Ceremony of the Alas Tribe in Southeast Ace. Journal of Social and Cultural Anthropology, 5(1), 40-50.

[4] Geria, I Made. 2005. Kajian Arkeologi Landskap Tantangan Ke depan dalam Pelestarian Warisan Budaya di Bali. Pertemuan Ilmiah Arkeologi (PIA X). Yogyakarta.

[5] Hendrawati \& Ermayanti. 2016. Wanita Perajin Tenun Tradisional Di Nagari Halaban, Kecamatan Lareh Sago Halaban Kabupaten Lima Puluh Kota, Sumatera Barat. Jurnal Antropologi: Isu-isu Sosial Budaya, 18(2), 69-87.

[6] Hodder, I. 1999. The Archaeological Process: An Introduction. Oxford: Blackwell.

[7] Majie, Zhu. 2002. Contemporary Culture and International Relations. In Yu Xintian, (ed.), Cultural Impact on International Relations. Washington, D.C.: Council for Research in Values and Philosophy.

[8] Moleong, Lexy. 2005. Metodologi Penelitian Kualitatif. Bandung: PT Remaja Rosdakarya.

[9] Wilson, Fisher, Crossen, \& Hemingway, 2018. Interdisciplinary Working Relationships of Health Care Staff in Late 20th Century Britain: A Cultural Study of Practices from the Past and Implications for the Present. IAFOR Journal of Cultural Studies, 3(2), 1-9.

[10] Dogeng. (https://id.wikipedia.org/wiki). 